\title{
PENGGUNAAN DAN PENGETAHUAN SUNSCREEN PADA MAHASISWA UNAIR
}

\author{
Michael Wadoe ${ }^{1)}$, Dwi S. Syifaudin ${ }^{1)}$, Wildhani Alfianna ${ }^{1)}$, Fini F. Aifa ${ }^{1)}$, Narlika D. P. ${ }^{1)}$, Rifdah A. Savitri. ${ }^{1)}$, \\ Margareta D. Andri. ${ }^{1)}$ Nuraini, Dinda M. Ikhsan ${ }^{1)}$, Aisyah Manggala ${ }^{1)}$, Intan Q.K. Fauzi ${ }^{1)}$, Nandya Ayu ${ }^{1)}$, \\ Mutrikah $^{1)}$, Arie Sulistyarini ${ }^{1)}$ \\ 1) Fakultas Farmasi Universitas Airlangga \\ Jl. Dharmawangsa Dalam Surabaya 60286 \\ E-mail: Michael.wadoe-2015@ff.unair.ac.id
}

\begin{abstract}
ABSTRAK
Paparan sinar matahari yang tinggi di Indonesia menyebabkan perlunya perlindungan terhadap kulit dengan pemakaian sunscreen. Wanita lebih sering menggunakan sunscreen daripada pria, oleh karena itu survei ini dilakukan untuk mengetahui tingkat pengetahuan dan perilaku dalam penggunaan sunscreen pada mahasiswa $\mathrm{S} 1$ pria. Metode yang digunakan dalam penelitian ini adalah survei dengan pengambilan sampel secara accidental sampling pada mahasiswa S1 pria di Universitas Airlangga. Teknik pengambilan data menggunakan kuesioner yang terdiri dari 15 pertanyaan tentang pengetahuan dan 8 pertanyaan tentang perilaku penggunaan. Dari 130 responden, $81 \%$ responden memiliki pengetahuan dengan kategori sedang, $14 \%$ responden memiliki pengetahuan dengan kategori rendah, dan hanya $5 \%$ responden yang memiliki pengetahuanb dengan kategori baik. Dari 130 responden, hanya 52 orang menggunakan sunscreen. Perilaku penggunaan sunscreen dari 52 responden tersebut menunjukan 51\% responden berkategori kurang, $49 \%$ responden berkategori sedang, dan tidak seorangpun responden berkategori baik. Hasil tersebut menunjukkan bahwa mayoritas tingkat pengetahuan dan perilaku responden survei ini dalam penggunaan sunscreen masih kurang baik, sehingga edukasi terkait pentingnya penggunaan sunscreen perlu dilakukan untuk memperbaiki kondisi ini.
\end{abstract}

Kata kunci: Universitas Airlangga, Sunscreen, Mahasiswa.

\begin{abstract}
High sun exposure in Indonesia causes the need for skin protection that can be accommodated by sunscreen. However, more women used sunscreen than men. This research was conducted to determine the level of knowledge and behavior in sunscreen use among male undergraduate students of Airlangga University. This study designed as a crosss sectional used accidental sampling. Data collection used a questionnaire consisting of 15 questions about knowledge and 8 questions about behavior. Of the 130 respondents, $81 \%$ respondents had moderate knowledge, $14 \%$ respondents had poor knowledge, and only 5\% respondents had good knowledge. Of the 130 respondents, only 52 respondents used sunscreen. The behavior toward sunscreen use among these 52 respondents showed that $51 \%$ of respondents were categorized as low, $49 \%$ of respondents were categorized as moderate, and none of the respondents was categorized as good. These results indicated that the knowledge and behavior of most respondents in the application of sunscreen was poor, thus education by giving information about the importance of sunscreen use is needed to improve this condition.
\end{abstract}

Keywords: Airlangga University, Sunscreen, Student. 


\section{PENDAHULUAN}

Indonesia merupakan negara tropis yang penuh dengan limpahan sinar matahari sepanjang tahunnya. Sinar matahari terdiri atas sinar dengan panjang gelombang 10-400 $\mathrm{nm}$ yang disebut dengan sinar ultraviolet (UV) (Isfardiyana dan Safitri, 2014). Dalam beberapa hal, sinar UV bermanfaat untuk manusia diantaranya untuk mensintesis vitamin D dan juga berfungsi untuk membunuh bakteri. Namun disamping manfaat tersebut, sinar UV juga dapat merugikan manusia apabila terpapar pada kulit manusia terlalu lama (BPOM, 2009).

Radiasi UV memiliki banyak efek negatif terhadap kulit, baik secara langsung maupun tidak langsung (Rabe et al., 2006; Rhein dan Santiago, 2010). Dampak negatif dari paparan sinar UV yang pertama adalah dapat membakar kulit dan itulah alasan mengapa saat keluar siang hari kulit terasa panas dan memerah. Setelah dingin, kulit kita akan menggelap akibat pembakaran tersebut. Kedua, sinar UV dapat menyebabkan kulit menjadi kusam, kering, dan keriput. Orang yang terpapar sinar UV setiap hari akan mengalami penuaan dini. Jaringan kolagen dan kelenjar minyak tidak lagi mampu melembabkan kulit dan meregenerasinya. Dampak paling mengerikan jika terus terpapar sinar ultraviolet adalah menderita kanker kulit. Bukan hanya kulit saja yang diserang, tapi juga kornea mata, hingga dapat mengakibatkan kerusakan mata akibat paparan sinar ulraviolet (Isfardiyana dan Safitri, 2014).

Kerusakan akibat sinar UV diperkirakan terjadi sekitar $50 \%$ akibat pembentukan radikal bebas (Reactive Oksigen Species/ ROS) (Rabe et al., 2006; Rhein dan Santiago, 2010). ROS dapat merusak DNA, menekan kekebalan tubuh, dan mengaktifkan bahan kimia dalam tubuh sehingga dapat menimbulkan kanker, menyebabkan kerusakan kulit, kulit terbakar (sunburn), eritema, menyebabkan noda-noda coklat, serta penebalan dan keringnya kulit. Pajanan yang berlebihan dan berlangsung lama dapat menimbulkan perubahan dan degenarasi pada kulit dan kanker kulit (Oroh dan Ekowati, 2001).

Penggunaan sediaan topikal sunscreen atau suntan lotion dalam jangka panjang sangat bermanfaat untuk menghindari penyakit yang disebabkan karena paparan sinar ultraviolet berlebih. Dikatakan bahwa wanita lebih sering menggunakan sunscreen daripada laki-laki. Lakilaki jarang menggunkan sunscreen namun lebih sering beraktivitas di luar ruangan dibandingkan wanita. Selain itu, wanita memiliki tingkat pengetahuan kanker kulit yang lebih tinggi daripada laki-laki dan percaya bahwa mereka lebih rentan terhadap kanker kulit dibandingkan laki-laki (Wickenheiser et al., 2013). Dituliskan juga oleh
Cody dan Lee (1990) bahwa pencegahan kanker bagi laki-laki masih lebih rendah dibandingkan dengan wanita. Kurangnya kesadaran dan edukasi serta maskulinitas masih menjadi alasan mengapa laki-laki enggan menggunakan sunscreen (Nurleili, 2009). Oleh karena itu, penelitian ini dilakukan dengan tujuan untuk mengetahui pengetahuan dan perilaku penggunaan sunscreen pada laki-laki dengan sasaran mahasiswa pria S1 Universitas Airlangga.

\section{METODE PENELITIAN}

Penelitian ini merupakan survei dengan menggunakan kuesioner sebagai instrumen dalam pengumpulan data. Pengumpulan data dilakukan di Universitas Airlangga, Surabaya. Responden yang dipilih adalah mahasiswa S1 pria yang berumur 1825 tahun.

Pengambilan sampel dilakukan dengan teknik accidental sampling. Kuesioner diawali dengan informed consent yang berisi nama, umur dan fakultas dari responden. Lalu dilanjutkan dengan 15 pertanyaan terkait pengetahuan mengenai sunscreen dan 8 pertanyaan terkait perilaku responden dalam menggunakan sunscreen. Validasi isi kuisioner dilakukan dengan merujuk pada pustaka dan validasi rupa yang dilakukan pada 13 orang dengan kriteria seperti responden. Variabel dalam penelitian ini adalah pengetahuan tentang sunscreen dan perilaku dalam penggunaan sunscreen.

Tabel 1. Kategori Pengetahuan dan perilaku penggunaan sunscreen

\begin{tabular}{|c|c|}
\hline Variabel & $\begin{array}{l}\text { Total Nilai } \\
\text { (Kategori) }\end{array}$ \\
\hline \multirow{3}{*}{ Pengetahuan } & $1-5 \quad$ (rendah) \\
\hline & 6-10 (sedang) \\
\hline & 11-15 (tinggi/baik) \\
\hline \multirow{3}{*}{ Perilaku } & 0-10 (kurang) \\
\hline & $11-21$ (sedang) \\
\hline & 22-32 (tinggi/baik) \\
\hline
\end{tabular}

Tingkat pengetahuan tentang sunscreen dan perilaku penggunaan ditunjukkan dengan total nilai dari jawaban responden. Untuk tingkat pengetahuan, apabila responden menjawab pertanyaan dengan benar maka diberi nilai 1 dan jika jawaban salah maka diberi nilai 0. Sedangkan untuk nilai perilaku penggunaan, apabila responden menjawab tidak pernah $=0$; jarang $=1$; kadangkadang $=2$; sering $=3$; selalu $=4$. Pengetahuan dan perilaku tersebut dibagi menjadi tiga kategori seperti terlihat pada Tabel 1. 


\section{HASIL DAN PEMBAHASAN}

Hasil survei diketahui sebanyak 52 dari 130 responden (40,0\%) menggunakan sunscreen (gambar 2). Responden dengan rentang umur 18-20 tahun terdiri atas 70 responden dan responden dengan rentang umur 21-25 tahun terdiri atas 60 responden.

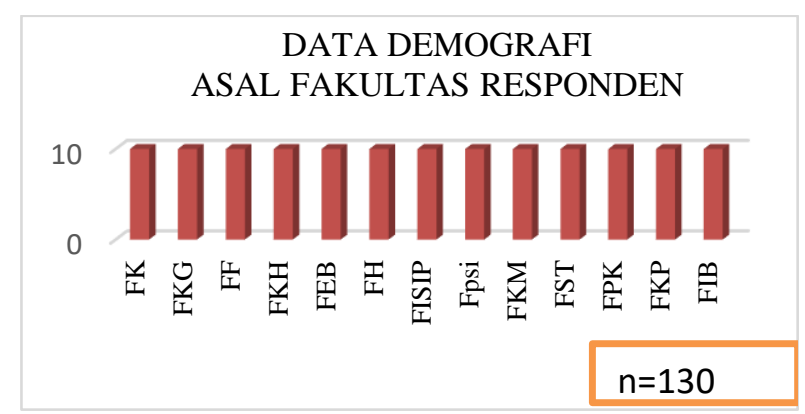

\section{Gambar 1. Data Demografi Asal Fakultas Responden}

Berdasarkan hasil survei dapat terlihat bahwa responden yang tidak menggunakan sunscreen lebih dari $50 \%$ yang tersebar pada berbagai rentang umur (18-25 tahun).

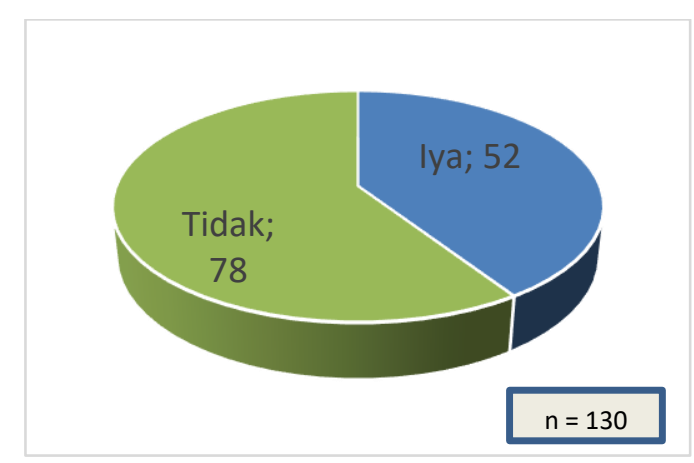

\section{Gambar 2. Penggunaan Sunscreen pada Responden}

Berdasarkan hasil studi dari Karen et al., di Amerika Serikat, diketahui kurang dari 15\% saja dari pria dewasa yang menggunakan sunscreen pada wajah maupun bagian tubuh mereka yang lain. Sedangkan di Indonesia, hanya $46,9 \%$ pria yang menggunakan sunscreen dari 720 responden sehingga hasil yang didapatkan pada penelitian ini sesuai dengan studi pendahulu yang telah dilakukan, bahwa penggunaan sunscreen pada pria masih tergolong rendah. Penelitian dari Lim et al (2009) dikatakan bahwa salah satu cara untuk meminimalisir paparan sinar UV dari matahari adalah menghindari melakukan kegiatan diluar ruangan pada pukul 10.00 pagi - 04.00 sore dimana sinar matahari bersinar paling kuat (Lim et al.,
2009). Namun hasil survei yang dilakukan menunjukkan sebanyak 41 responden $(31,54 \%)$ sering melakukan aktivitas di luar ruangan pada jam tersebut, 39 responden $(30 \%)$ yang kadangkadang beraktivitas di jam tersebut, 34 responden $(26,15 \%)$ jarang beraktivitas pada jam tersebut, dan sebanyak 16 responden $(12,31 \%)$ yang selalu beraktivitas di luar ruangan pada jam 10.00 pagi04.00 sore. Hal ini juga didukung oleh survei yang dilakukan oleh Hill et al (1984) di Indonesia, bahwa sebanyak $17,2 \%$ dari 720 responden menghabiskan waktu di luar ruangan selama lebih dari 7 jam pada pukul 08.00 pagi - 05.00 sore pada akhir minggu dan sebesar $16,4 \%$ pada hari-hari biasa. Hal ini menunjukkan bahwa aktivitas di luar ruangan pada jam-jam dimana sinar UV memancar paling banyak masih tinggi, sehingga penggunaan sunscreen pada jam-jam tersebut sudah tepat dilakukan.

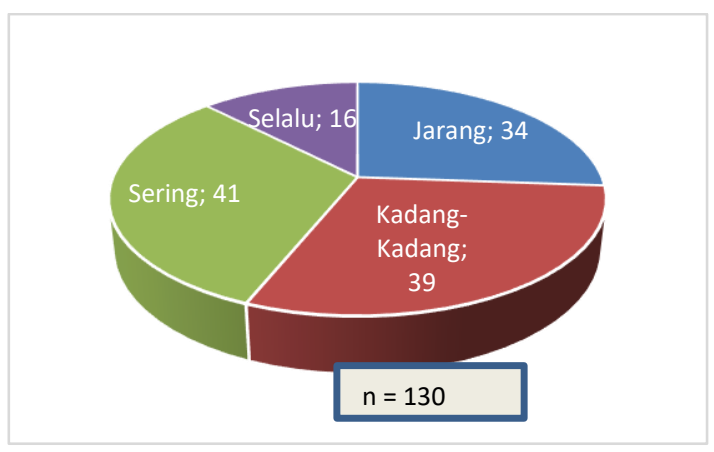

\section{Gambar 3. Aktivitas responden di luar ruangan pada pukul 10.00 AM -16.00 PM}

Berdasarkan komposisinya, sunscreen dibagi menjadi 2 yaitu Chemical dan Physical Sunscreen. Chemical sunscreen atau organic sunscreen adalah pelindung yang bekerja dengan menyerap sinar matahari sedangkan physical/ nonorganic sunscreen bekerja dengan memantulkan sinar matahari (Zaid et al., 2018). Dari survei yang telah dilakukan, sebanyak 113 orang mengetahui tentang perbedaan mekanisme kerja dari Chemical dan Physical Sunscreen. Menurut Johnson dan Lookingbill (1984), terdapat 3 macam jenis radiasi sinar UV yaitu UV A, UV B, dan UV C. Namun, hasil survei menunjukkan hanya 39 responden $(\mathrm{n}=130)$ yang mengetahui macam-macam radiasi UV tersebut.

Hasil survei juga menunjukkan bahwa hanya 38 dari 130 responden yang mengetahui paparan sinar UV dapat menimbulkan penuaan dini. Penggunaan sunscreen dapat mencegah terjadinya penuaan dini akibat sinar UV. Sinar UV A dapat menyebabkan penuaan dini karena mendegradasi matriks kulit. Radiasi UV A masuk ke dalam matriks kulit dan dapat bereaksi dengan oksigen 
menghasilkan radikal bebas yang menyebabkan collagen cross - linking dan kerusakan fibroblast kulit (Karen et al., 2009). Sinar UV juga bertanggung jawab pada kerusakan jaringan elastis (Menter dan Hatch, 2003).

Sebanyak 99 dari 130 responden menjawab dengan benar bahwa sinar UV A dapat mengakibatkan penggelapan kulit. Hal ini menunjukkan bahwa responden sudah memiliki pengetahuan mengenai efek radiasi sinar UV A dengan baik. Radiasi sinar UV A mengakibatkan kulit menjadi hitam atau gelap sebab sinar UV A berpenetrasi lebih dalam pada dermis yang menyebabkan penuaan dini pada kulit (Menter dan Hatch, 2003). Selain itu, 98 dari 130 responden menjawab dengan benar bahwa jenis radiasi UV B dapat menyebabkan kanker kulit. Radiasi sinar UV B lebih banyak mengakibatkan kerusakan pada kulit bahkan menimbulkan kanker kulit (Mukti, 2014).

Sebanyak 104 dari 130 responden mengetahui tentang manfaat broad-spectrum sunscreen yang berfungsi melindungi kulit terhadap sinar UV A dan UV B. Hal ini sesuai dengan penelitian Stefan et al (2017) yang menyebutkan bahwa broad spectrum adalah produk sunscreen yang dapat memberikan perlindungan terhadap UVA dan UVB.

Tabel 2. Pernyataan Pengetahuan tentang Sunscreen dan jumlah Responden menjawab dengan Tepat (n=130)

\begin{tabular}{clc}
\hline No & \multicolumn{1}{c}{ Pernyataan } & $\begin{array}{c}\text { Jawaban Tepat } \\
\text { n }(\%)\end{array}$ \\
\hline 1 & $\begin{array}{l}\text { Chemical Sunscreen (organic sunscreen) adalah pelindung yang bekerja dengan } \\
\text { menyerap sinar matahari, sedangkan Physical sunscreen (inorganic } \\
\text { sunscreen atau sunblock) bekerja dengan memantulkan sinar matahari }\end{array}$ & $113(86.9)$ \\
\hline 2 & SPF adalah singkatan dari Sun Photochemistry Factor & $28(21.5)$ \\
\hline 3 & $\begin{array}{l}\text { Broad Spectrum Sunscreens (sunscreen spektrum luas) merupakan sunscreen yang } \\
\text { dapat melindungi kulit dari radiasi sinar } U V A \text { \& } U V B\end{array}$ & $104(80,0)$ \\
\hline 4 & Sunscreen digunakan 1-2 jam sebelum melakukan aktivitas di luar ruangan & $62(47.7)$ \\
\hline 5 & Hanya ada dua macam jenis radiasi sinar $U V$ & $39(30,0)$ \\
\hline 6 & $\begin{array}{l}\text { Jenis radiasi sinar } U V \text { A merupakan sinar } U V \text { yang dapat memberikan efek penuaan pada } \\
\text { kulit dan membuat kulit menjadi hitam/gelap }\end{array}$ & $99(76.2)$ \\
\hline 7 & $\begin{array}{l}\text { Jenis radiasi sinar } U V \text { yang dapat menyebabkan terjadinya Sunburn bahkan kanker pada } \\
\text { kulit adalah } U V B\end{array}$ & $97(74.6)$ \\
\hline 8 & $\begin{array}{l}\text { Jenis radiasi sinar } U V \text { yang dapat menembus kulit lebih dalam hingga ke bagian dermis } \\
\text { adalah } U V B\end{array}$ & $39(30,0)$ \\
\hline 9 & $\begin{array}{l}\text { Penggunaan Sunscreen itu penting pada siang hari baik dalam aktivitas indoor maupun } \\
\text { outdoor }\end{array}$ & $76(58.5)$ \\
\hline 10 & Penggunaan Sunscreen dapat mencegah terjadinya penuaan dini akibat sinar UV & $88(67.7)$ \\
\hline 11 & Penggunaan Sunscreen dapat mencegah kanker kulit & $90(69.2)$ \\
\hline 12 & Anda menggunakan sunscreen adalah untuk menjaga kulit tetap putih. & $63(48.5)$ \\
\hline 13 & Pemakaian Sunscreen perlu diulang setiap 3-5 jam & $81(62,3)$ \\
\hline 14 & SPF yang paling direkomendasikan adalah SPF 15 & $40(30,8)$ \\
\hline 15 & Pengulangan penggunaan sunscreen perlu setelah berkeringat dan berenang & $66(50.76)$ \\
\hline
\end{tabular}

Dari 130 responden, 90 orang mengetahui bahwa penggunaan sunscreen dapat mencegah kanker kulit. Hal tersebut sesuai dengan penelitian terdahulu yang menjelaskan bahwa sunscreen tidak hanya melindungi kulit dari sunburn, tapi juga melindungi dari kanker kulit yang disebabkan oleh UV dengan mekanisme menurunkan dimer siklobutana pirimidin (Sergio, 2011).

Sebanyak 63 dari 130 responden beranggapan bahwa penggunaan sunscreen dapat menjaga kulit tetap putih. Padahal sunscreen tidak ditujukan untuk menjaga kulit tetap putih (Karen et al., 2009). Namun, tujuan utama penggunaan sunscreen adalah untuk melindungi kulit dari sunburn yang diakibatkan oleh radiasi UV dan untuk mencegah kanker kulit (Karen et al., 2009).

Hanya 28 dari 130 responden mengetahui kepanjangan dari SPF. SPF (Sun Protecting Factor) adalah angka yang menunjukkan seberapa lama produk dapat melindungi manusia dibawah terik matahari (Mukund et al., 2016).

Selanjutnya, hanya 40 dari 130 responden yang menjawab dengan benar bahwa SPF 15 bukan merupakan SPF yang paling direkomendasikan. Penggunaan sunscreen pada daerah tropis dibutuhkan SPF lebih dari 15 yaitu SPF 30 karena seringkali SPF yang terdapat pada label tidak selalu berisi sama, kadang kala hanya $80 \%$ dari label. Sehingga untuk menghindari eritema dan sunburn diperlukan SPF 30+ (Poon and Barnetson, 2002).

Sebanyak 76 dari 130 responden mengetahui pentingnya penggunaan sunscreen baik indoor maupun outdoor. Penggunaan sunscreen baik digunakan dalam keadaan apapun. Semakin sering 
beraktivitas di luar ruangan, artinya semakin besar intensitas terpapar sinar UV sehingga perlu digunakan sunscreen untuk mencegah bahaya dari sinar UV (Lim et al., 2009).

Hasil survei pada Tabel 2 menunjukkan bahwa 62 dari 130 responden menjawab dengan benar bahwa sunscreen digunakan 1-2 jam sebelum melakukan aktivitas di luar ruangan, sedangkan 68 lainya menjawab dengan salah. Padahal sunscreen sebaiknya digunakan 15-30 menit sebelum keluar ruangan (Farberg et al., 2017).

Berdasarkan Tabel 2, hasil survei menunjukkan bahwa 81 dari 130 responden beranggapan bahwa penggunaan sunscreen perlu diulang setiap 3 hingga 5 jam. Padahal sunscreen harusnya diaplikasikan kembali paling lambat setiap 2 jam selama beraktivitas di bawah sinar matahari, sunscreen juga perlu digunakan meskipun pada cuaca mendung (Lim et al., 2009).

Hal ini menunjukkan bahwa pengetahuan responden tentang sunscreen masih tergolong masih rendah. Gambar 4 menunjukkan bahwa dari 130 responden sebanyak 7 responden memiliki pengetahuan yang kurang baik, 13 responden memiliki pengetahuan baik dan sebanyak 110 responden memiliki tingkat pengetahuan sedang. Nilai rata-rata tingkat pengetahuan responden tentang sunscreen dari 130 responden adalah 7,3 yang jauh di bawah nilai 32 yang merupakan nilai tertinggi dari tingkat pengetahuan survei ini. Sebanyak 53 dari 130 responden memiliki pengetahuan di atas rata-rata dan sebanyak 67 responden memiliki pengetahuan di bawah ratarata. survei ini memiliki pengetahuan yang masih rendah terkait sunscreen.

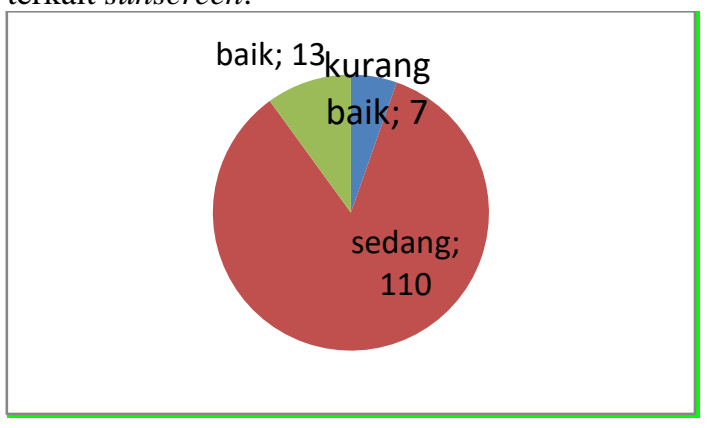

\section{Gambar 4. Tingkat pengetahuan responden tentang sunscreen}

Selanjutnya pada bagian terakhir dari kuesioner berisi tentang perilaku responden dalam penggunaan sunscreen. Bagian ini hanya diisi oleh responden yang menjawab pernah menggunakan sunscreen (52 dari 130 responden). Pertanyaan pertama menanyakan mengenai penggunaan sunscreen secara teratur setiap hari. Penggunaan sunscreen yang teratur dimaksudkan untuk meningkatkan efektivitas dari sunscreen dalam melindungi kulit dari sunburn, melanoma, penuaan sel dan yang lainnya. Pada literatur yang lain dianjurkan untuk menggunakan 15-30 menit sebelum aktivitas diluar gedung serta diulang setiap 2 jam, sehingga bisa disumpulkan bahwa sunscreen dianjurkan dipakai secara teratur (Lim et al., 2009).

Tabel 3. Hasil Jawaban Responden tentang Perilaku Menggunakan Sunscreen

\begin{tabular}{|c|c|c|c|c|c|c|}
\hline $\begin{array}{l}\mathrm{N} \\
\mathrm{o}\end{array}$ & Pertanyaan & Selalu & Sering & $\begin{array}{c}\text { Kadang } \\
- \\
\text { kadang } \\
\end{array}$ & Jarang & $\begin{array}{l}\text { Tidak } \\
\text { pernah }\end{array}$ \\
\hline 1 & $\begin{array}{l}\text { Anda menggunakan sunscreen secara teratur } \\
\text { setiap hari }\end{array}$ & 1 & 4 & 15 & 28 & 4 \\
\hline 2 & $\begin{array}{l}\text { Anda mengoleskan ulang Sunscreen setiap } 2 \text { jam } \\
\text { setelah pemakaian }\end{array}$ & 0 & 1 & 4 & 15 & 32 \\
\hline 3 & Anda mengoleskan ulang Sunscreen sebelum berenang & 3 & 7 & 12 & 13 & 17 \\
\hline 4 & $\begin{array}{l}\text { Anda mengoleskan ulang Sunscreen setelah } \\
\text { berkeringat dan berenang }\end{array}$ & 0 & 0 & 7 & 11 & 34 \\
\hline 5 & $\begin{array}{l}\text { Anda membeli kembali Sunscreen apabila sunscreen } \\
\text { yang anda miliki sudah habis }\end{array}$ & 6 & 9 & 15 & 11 & 11 \\
\hline 6 & $\begin{array}{l}\text { Anda memilih Sunscreen yang memiliki perlindungan } \\
\text { terhadap UV A dan UV B }\end{array}$ & 10 & 14 & 11 & 10 & 7 \\
\hline 7 & $\begin{array}{l}\text { Anda menggunakan sunscreen } 15-30 \text { menit sebelum } \\
\text { melakukan aktivitas di luar ruangan }\end{array}$ & 2 & 12 & 14 & 19 & 5 \\
\hline 8 & $\begin{array}{l}\text { Anda menggunakan sunscreen saat berada di dalam } \\
\text { ruangan }\end{array}$ & & 2 & & 12 & \\
\hline & $\begin{array}{l}\text { eskipun mayoritas responden memiliki } \\
\text { pengetahuan sedang tetapi responden lebih } \\
\text { yang memiliki pengetahuan di bawah rata- } \\
\text { ka dapat dikatakan bahwa responden pada }\end{array}$ & $\begin{array}{l}\text { respo } \\
\text { sebel } \\
\text { kadar } \\
\text { perna }\end{array}$ & $\begin{array}{l}\text { en } \\
\text { merel } \\
\text { nenga } \\
\text { nengat }\end{array}$ & $\begin{array}{l}\text { men } \\
\text { raktivi } \\
\text { sikann } \\
\text { ikan } s\end{array}$ & $\begin{array}{l}\text { likasil } \\
15 \text { res } \\
\text { dan } 4 \\
\text { creen. }\end{array}$ & $\begin{array}{l}\text { sunscreen } \\
\text { en kadang- } \\
\text { nden tidak }\end{array}$ \\
\hline
\end{tabular}


Berbeda dengan data survei Prasetyowati (2011) perilaku responden pada penelitian yang dilakukan oleh Prasetyowati (2011) sudah cukup baik karena mereka tetap menggunakan sunscreen walaupun jarang dan tetap mendapatkan efek sunprotection.

Pertanyaan kedua menanyakan tentang cara penggunaan sunscreen setiap 2 jam setelah pemakaian. Untuk melindungi kulit dari sinar matahari yang merugikan manusia, ada instruksi yang mudah dilakukan tetapi memiliki efek besar.

Sehingga direkomendasikan pengolesan kembali setiap 2 jam untuk tetap memberikan perlindungan maksimal terhadap kulit (Lim et al., 2009). Namun, hasil survei menunjukkan 32 responden tidak pernah mengoleskan kembali setiap 2 jam dan 15 responden jarang melakukannya. Alasan responden berperilaku kurang baik dalam penggunaan ulang karena kurangnya pengetahuan dan kepedulian terhadap kondisi kulit selama terpapar matahari.

Pertanyaan ketiga dan keempat tentang penggunaan kembali sunscreen sebelum dan sesudah berenang. Dalam buku London Health Sciences Center (2011) menyebutkan bahwa sunscreen diaplikasikan 30 menit sebelum keluar. Sedangkan pada jurnal Fotoproteksi (Subchan et al., 2011) menyatakan bahwa penggunaan ulang dibutuhkan sesudah berenang, berkeringat, dan menggosok tubuh. Pada pertanyaan ketiga sebanyak 17 responden menjawab tidak pernah, 13 responden jarang, setiap 12 responden menjawab kadang-kadang, 7 menjawab responden sering, 3 menjawab selalu menggunakan kembali sunscreen sebelum berenang. Sedangkan untuk pertanyaan keempat mengenai pengolesan ulang sunscreen setelah berkeringat dan berenang, hasil survei menunjukkan 34 responden menjawab tidak pernah, 11 responden jarang, setiap 7 responden menjawab kadang-kadang, tidak seorangpun dari responden menjawab sering, tidak seorangpun dari responden menjawab selalu menggunakan sunscreen setelah berenang.

Pertanyaan kelima tentang pembelian sunscreen kembali setelah habis. Pengaplikasian sunscreen harus diulang tiap 2 jam sekali, sehingga apabila sunscreen habis seharusnya melakukan pembelian ulang sunscreen (London Health Sciences Center, 2011). Namun, hasil survei menunjukkan 11 responden menjawab tidak pernah, 11 responden jarang, setiap 15 responden menjawab kadang-kadang, 9 menjawab responden sering, 6 responden menjawab selalu. Dari data yang didapatkan bahwa responden berperilaku kadang-kadang membeli kembali saat sunscreen sudah habis.

Pertanyaan keenam menanyakan tentang cara memilih sunscreen yang memiliki perlindungan terhadap UV A dan UV B. Sunscreen yang baik adalah yang memberikan proteksi terhadap UV A dan UV B, karena setiap produk sunscreen yang beredar di pasaran memiliki perbedaan daya proteksi terhadap UV A dan UV B dan untuk pemilihan sunscreen disarankan untuk berkonsultasi pada apoteker (London Health Sciences Center, 2011). Namun, hasil survei menunjukkan 7 responden menjawab tidak pernah, 10 responden jarang, setiap 11 responden menjawab kadang-kadang, 14 menjawab responden sering, 10 responden menjawab selalu. Dari data yang didapatkan bahwa responden berperilaku sering memilih sunscreen yang memiliki perlindungan terhadap UV A dan UV B.

Pertanyaan ketujuh menanyakan tentang cara penggunaan sunscreen sebaiknya 15-30 menit sebelum melakukan aktivitas di luar ruangan. Penggunaan sunscreen sebaiknya dilakukan 15-30 menit sebelum keluar ruangan dan sebaiknya digunakan ulang setiap dua jam selama masih terpapar sinar matahari (Lim et al., 2009). Namun, hasil survei menunjukkan 5 responden menjawab tidak pernah, 19 responden jarang, setiap 14 responden menjawab kadang-kadang, 12 menjawab responden sering, 2 responden menjawab selalu. Hal tersebut menunjukkan bahwa dalam penggunaan sunscreen responden jarang menggunakan 15-30 menit sebelum keluar ruangan.

Pertanyaan kedelapan menyatakan bahwa penggunaan sunscreen sebaiknya juga digunakan saat berada di dalam ruangan, dalam keadaan apapun sebaiknya tetap menggunakan sunscreen (London Health Sciences Center, 2011). Namun, hasil survei menunjukkan 33 responden menjawab tidak pernah, 12 responden jarang, setiap 5 responden menjawab kadang-kadang, 2 menjawab responden sering, 0 responden menjawab selalu.

Hasil penilaian jawaban 52 responden terkait perilaku mereka dalam penggunaan sunscreen dikelompokkan menjadi tiga kategori seperti terlihat pada Gambar 4. Dari hasil survei diperoleh data bahwa mayoritas responden (48 orang) dinyatakan berperilaku kategori kurang dalam menggunakan sunscreen, hanya 4 orang dalam kategori sedang dan tidak seorangpun berperilaku baik. Selain itu, nilai rata-rata perilaku penggunaan adalah 9,8 yang jauh di bawah nilai tengah (16 dari total nilai 32). 


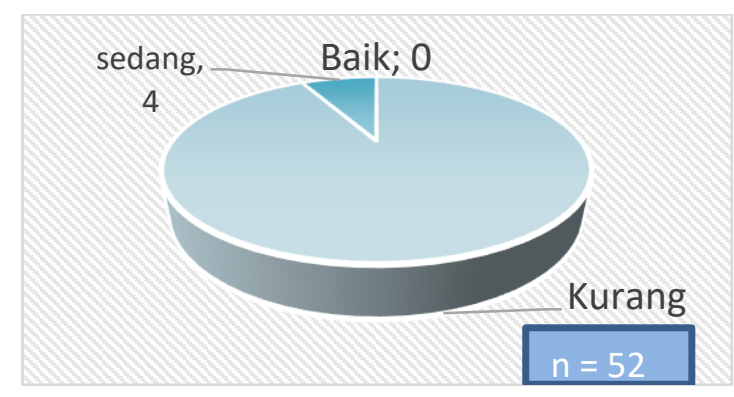

Gambar 5. Perilaku responden dalam
penggunaan sunscreen

\section{KESIMPULAN}

Dari 130 responden, 78 responden tidak pernah menggunakan sunscreen padahal sebanyak 41 orang sering beraktifitas pada pukul 10.0016.00. Skor rata-rata pengetahuan tentang sunscreen dari 130 responden adalah 7,3 yang jauh di bawah nilai 15 yang merupakan skor tertinggi dari tingkat pengetahuan survei ini serta skor ratarata perilaku penggunaan dari 52 responden yang hanya 9,8 jauh dibawah 32 yang meupakan skor tertinggi dari tingkat perilaku sehingga dapat disimpulkan pengetahuan dan perilaku responden masih kurang baik. Oleh karena itu perlu dilakukan edukasi lebih lanjut untuk memperbaiki perilaku masyarakat terkait penggunaan sunscreen dan meningkatkan pengetahuan mereka tentang sunscreen itu sendiri.

\section{Ucapan Terima Kasih}

Ucapan terima kasih diberikan kepada dosen pembimbing Praktikum Farmasi Masyarakat yaitu Ibu Arie Sulistyarini, S.Si., M.Pharm., Apt. yang telah membimbing kami dalam penelitian dan penulisan naskah publikasi ini serta mahasiswa Universitas Airlangga yang telah ikut berpartisipasi menjadi responden dalam penelitian ini.

\section{DAFTAR PUSTAKA}

Anonim. 2009. Badan Pengawas Obat dan Makanan 2009 Naturakos Edisi 11. Indonesia : Kementrian Kesehatan RI

Cody, R., and Lee, C. 1990. Behaviors, beliefs, and intentions in skin cancer prevention. J. Behav. Med. 13: 373-389

Farberg AS., Glazer AM., Rigel AC., White Richard., Rigel DS., 2017. Dermatologists' perceptions, recommendations, and use of sunscreen. JAMA dermatology, 153(1), 99-101

Hill, D., Rassaby, J., dan Gardner, G. 1984. Determinants of intentions to take precautions against skin cancer. Commun. Health Stud. 8: 33-44.

Isfardiyana, SH dan Safitri, SR, 2014 Pentingnya melindungi kulit dari sinar ultraviolet dan cara melindungi kulit dengan sunblock buatan sendiri, Inovasi dan Kewirausahaan, 3(2), pp. 126-133.

Johnson, EY dan Lookingbill, DP, 1984. Sunscreen use and sun exposure. Arch. Dermatol 120: 727-73.

Karen G., Frances M., Eric J., Nehl, David LO., Peter G, Lucja, B EdM., Adam E., Locke, BA., Dawn, M H. 2009. Validity of SelfReported Sunscreen Use by Parents, Children, and Lifeguards, American Journal of Preventive Medicine, Published by Elsevier.

Lim, HW dan Draoles, ZD, 2009. Clinical Guide to Sunscreen and Photoprotection. Informa Health Care New York London.

London Health Science Center. 2011. London Regional Cancer Program. London Herzog.

Menter J.M. dan Hatch, K.L. 2003. Clothing as Solar Radiation Protection, Curr Probl. Dermatol. Basel: Karger.

Mukti dan Andriani, R. 2014. Tabir Surya Vs Iklim Tropis, Prodi PKK Tata Rias - FKIP. Skripsi. Universitas PGRI Adi Buana Surabaya.

Mukund MD., Sharada LD., 2016. Journal pharmacognosy. Volume 8. Sunscreen : A review. Department of Pharmaceutical Science, India.

Nurleili F., 2009. Laki-laki pengguna produk kosmetik: Sebuah Studi Interpretatif Konstruktivis Tentang Identitas Diri. Surabaya. Skripsi. Jurusan Sosiologi Fakultas Ilmu Sosial dan Ilmu Politik Universitas Airlangga.

Oroh, E. dan Ekowati, S.H. 2001. Tabir Surya (Sunscreen) Vol. 13 (1). Skripsi. Universitas Airlangga, Surabaya.

Poon, TS dan Barnetson, RS. 2002. The importance of using broad spectrum SPF 30+ sunscreens in tropical and subtropical climates.Photodermatology,photoimmunolo gy \& photomedicine, 18(4), 175-178.

Subchan P, Diah, AM dan Wieke, TN, 2011. Fotoproteksi. MDVI 2011, Vol. 38, pp. 141148

Rabe, JH, Mamelak, AJ, McElgunn, PJS, Morison, WL, dan Sauder, DN, 2006. Photoaging: Mechanisms and repair. Journal of the American Academy of Dermatology, 55(1), 1-19. doi:10.1016/j.jaad.2005.05.010

Rhein, LD, Santiago JM. 2010. Agent Skin : Current and Future Therapeutic Strategies $1^{\text {est }}$ In USA. Allu Red Bussines Media p 2681. 
Sergio. 2011. Sun Protection Factor : Meaning and Controversies. Brazil. Anais Brazileiros De Dermatologi.

Stefan M., Lim, H W., Wiliams, M S., Maddalena, I D., De and Osterwalder, U. 2017. Sun Protection Factor Comunication of Sunscreen Effectiveness : a web-based study of perception of effectiveness by dermatology. JAMA Dermatology, 153(3).

Wickenheiser, M., Baker, M.K., Gaber, R., Blatt, H., Robinson, J.K. 2013. Sun Protection Preferences and Behaviors among Young Adult Males during Maximum Ultraviolet Radiation Exposure Activities. Int. J. Environ. Res. Public Health 2013, 10, 3203-3216.doi: 10.3390/ijerph10083203

Zaid, A N., Jaradat, N., Darwish, S., Nairat, S., Shamlawi, R., Hamad, Y., Hussein, F and Isa, L. 2018. Assesment of The General Quality of Sunscreen produk available in Palestina and
Method Verification of The Sun Protection Factor Using Food and Drug Adsministration Guidelines. Journal of Cosmetic Dermatology. 